\title{
The Role Which Faculty Members at Al-Hussein Bin Talal University Have the Principles of Brain-Based Learning Theory
}

\author{
Prof. Omar Al-Khateeb \\ Al-Hussein Bin Talal University,PO BOX 20, maan,Jordan
}

\begin{abstract}
:
The aim of this study was to find out the extent to which the faculty members of Al-Hussein Bin Talal University have the principles of learning theory based on the brain. The study sample consisted of 70 faculty members, of which 54 were male faculty members. The researcher used the questionnaire tool to measure the extent principles of the faculty members of brain-based learning theory. The results showed the following:

1. The faculty members have knowledge of the principles of brain-based learning.It came in the first place with a high degree field (realized that every brain is unique). The field came at the last and intermediate level (I know that the brain is designed to recognize and generate patterns).

2. There are statistically significant differences for faculty members who have more than 10 years' experience to own the principles of brain-based learning theory.

3. There are no statistically significant differences due to gender in the extent of ownership faculty members at Al-Hussein Bin Talal University.
\end{abstract}

Keywords: principles of brain, learning theory.

DOI: $10.7176 / \mathrm{JEP} / 11-5-06$

Publication date: February $29^{\text {th }} 2020$

\section{Introduction:}

The educational research witnessed an important shift in the consideration of the learning process, where many questions arose about what is going on inside the learner's brain, how to form his mind, how to develop the potential of learners, and develop their mental capabilities as fully as possible. The theory of brain-based learning appeared in the last decade of the twentieth century and specifically In the nineties and the most famous of these views: Caine \& Caine, Eric Jensen, David Sousa, and other scientists who have benefited from brain research and its functions and how to use them in the educational process (Al-Salti, 2009).

This theory represents an approach to teaching and learning as it is based on the principles of neuroscience, which in turn explains how and the mechanism of the brain works naturally. The theory of learning based on the brain is based on the structure and functions of the brain. Of the nerve connections, and the complexity of the various brain connections that translate the types of relationships as levels (sensory, semi-abstract, or abstract) (Flambani, 2014).

\section{Brain-based learning concept:}

Caine (1997) defines brain-based learning as: applying a set of meaningful principles that represent the current human understanding of how the brain works in the context of education, where the idea of brain-based learning revolves that learning will be more effective for students if activities are conducted in an atmosphere It is compatible with the way the brain learns, and the main principle is: that learning will be more effective if it is done in the natural environment of the learner which is a challenge without a threat, it focuses on how the brain learns, and calls for organizing teaching according to these rules by making Learning is meaningful for students, as the whole brain is used.

Kattami (2007) defines brain-based learning as "a comprehensive method or approach to teaching and learning that makes students more productive, teachers less frustrating and changes their perception of their students, as this theory is based on the structure and function of the brain and as long as the brain has not prevented from performing its natural processes Learning will happen, a theory supported by cognitive psychology research.

As for Jensen (2000), brain-based learning is defined as "a theory of learning that emphasizes learning with the presence of mind, in the presence of high arousal, realism, pleasure, suspense, fun, cooperation, absence of threat, multiplicity and overlapping of systems in the educational process and other than This is a characteristic of learning in harmony with the brain.

\section{The Theoretical Principles and Assumptions Underlying Brain-based Learning:}

The principles of brain-based learning theory are summarized as follows: (Caine \& Caine 1990)

1 - The brain is a vital organ: the brain's physiology senses and functions work with the body as a single dynamic unit in the learning process.

2 - The brain is social in nature. 
3-Searching for meaning is an instinct innate process in the brain.

4- The search for meaning takes place through stereotyping. Meaning is much more important to the brain than information.

5- Emotion is a necessary factor in learning and stereotyping, as it provides the learner with attention, meaning and memory.

6- The brain deals with a whole and paricials simultaneously.

7- Learning includes both focus and lateral perception.

8- There are two types of memory: spatial space memory and memorizing memory.

9- Learning is a constructive, evolutionary process.

10 - Learning is reinforced by motivation and challenge, discouraged by fear and intimidation.

\section{The brain-based learning theory is based on several assumptions, including:}

1 - The brain is the leader and controller of all body activities.

2- Learning is an inseparable relationship between the body and the brain and reason and thinking do not occur in isolation from the structure of the body.

3- The brain is an adaptive system, and experience is achieved through the intertwining of millions of neurons.

4- The brain is not stationary but a dynamic, resilient organ that grows through experience.

5- Learning is a physiological process that is carried out through three features: balanced treatment, overlap between brain components and elements and brain flexibility.

6- Brain-based learning is affected by the environment surrounding its full data, such as nutrition and movement. Therefore, attention should be paid to studying the best conditions in which the brain learns.

7-The brain improves by using the left and the right sides of the brain.

8-The learner's brain loses the desired meaning if the educational experiences exposed to upper or lower level.

9-Brain abilities are affected over time.

10-Brain capabilities increase through interaction and cooperation with others (Al-Qarni, 2015).

11-The unique important feature of an individual's thinking is that it is constantly changing.

12-In early life, an overflow of nerve connections occurs in the brain, demonstrating an enormous ability to adapt to variations in experience (Kim, 2009).

\section{The stages that underlie brain-based learning:}

Brain-based learning is based on five stages, which are as follows: (Abdul Karim, 2010)

1- Preparation, which means: forming an idea about the topic and forming a mental perception of related topics. The more the learner has a background on the topic, the faster he will be in representing and processing new information.

2- The acquisition that takes place through the formation of neural correlations as a result of original and interconnected experiences. Neural correlations become stronger and more whenever the inputs are interconnected, and if the inputs are familiar, the reinforced correlations are strengthened and learning is produced.

3- Detail that is based on revealing the interconnectedness of subjects, deepening understanding and needs to integrate students into class activities for deeper understanding and feedback with explicit and implicit strategies, and continuous correction and adjustment is an important method of learning.

4- The formation of memory that aims to strengthen learning and better retrieve information through: adequate rest, emotional acuity, context, feedback, learning situations and tribal learning, which helps to deepen brain therapy and better learning.

5- Functional integration in which new learning is used, with the aim of strengthening it later and expanding it and expanded or extended neural networks are developed through: forming interlink ages, developing valid interlink ages and strengthening those interconnections.

\section{Teaching techniques accompanying brain-based learning are:}

1- Coordinated immersion: It is intended to create learning environments that students dip into educational experiences.

2-Relaxed indulgence: It is intended to attempt to eliminate the fear felt by the learner, and at the same time maintain a learning environment with high specifications.

3-Active Processing: It is intended to allow the learner to acquire and analyze information by processing it effectively. 


\section{The importance of brain-based learning:}

The importance of brain-based learning stems from the fact that Burnet (2010, Burnet, 2010) emphasizes providing a helping hand to educators and officials to create an effective learning environment, suitable for individuals.

The development of the educational process is a comprehensive and continuous process, as it is not limited to attention to the curricula in terms of modifying and developing them, or attention to the content of the study materials that are presented to the learner, but it is also concerned with other aspects of the educational process, such as the interaction between the teacher and the learner and the use of modern strategies that stimulate learning, and encourages students to do more, give opportunities to practice and provide more freedom to learn. (Joma, 2009).

The interest in developing education is due to being the main pillar in the progress that all countries of the world seek in various fields through the consensus of thinkers and those concerned with development and this approach supports many experiences that have taken place on the ground, including the report issued by the International Committee for Education for the twenty-first century, which belongs to UNESCO. It emphasized that education officials in the countries of the world address the problem of the quality of education from its fundamental aspects, which is represented in improving the academic, professional, theoretical and practical competencies of teachers). UNESCO, 1997.(

Under the title "Building Human Capacity: Education", the Human Development Report mentioned the role of the teacher in the educational learning process as the focus of the innovative work, as policies give the role of the teacher an increasing importance and a greater affair; it involves a fundamental change in the teacher's job roles and turns with him to guide sources Knowledge and learning, a coordinator of learning processes, a correction of learning mistakes, and a rectifier for learning outcomes, directed to what suits the capabilities and inclinations of each learner, and the teacher should be prepared and trained in the framework of the fundamental change that must take place in the structure, curricula and methods of education, and in its basic goals, especially with regard to The teacher practiced the methods of self-learning, education through the team of teachers and methods of cooperation with parents and the local community and training him on new means in evaluating students, and on educational guidance, and linking basic education to the needs of society and work sites, and this requires a teacher of a new model, and preparing the teacher in an appropriate preparation of goals Updated, and continuous training for it on educational developments (Regional Office for Arab States, 2002).

Therefore, interest in CBTE programs increased so that they were used extensively in most of the programs used in developed countries, and UNESCO developed many training programs in developing countries based on the principles upon which the competency-based teacher education has emerged. This movement developed as a result of the constant complaint that the prevailing education programs are unable to relate to the contemporary needs of man and his ability to face the reality of the age in which he lives, and that these programs have not achieved a significant change in the performance of graduates (Al-Naga, 1997).

With the spread of this movement, teacher training programs have emerged and these programs have spread to even most of the colleges of teacher preparation in America. This movement is based on a major postulate that the teaching process can be analyzed into a set of competencies and teacher training for students and this ensures the preparation of teachers at a high level of competence. (Jami, 1999).

And based on the above on the need to develop the performance of teachers and because the researcher feels that there are deficiencies among faculty members in the ownership of principles of brain-based learning, accordingly, this study came to research in determining the extent of faculty members owning a university AlHussein bin Talal for brain-based learning principles.

\section{The study problem and its questions:}

Based on the foregoing, the study problem is determined in the following main question: "To what extent do members of the teaching staff at Al-Hussein Bin Talal University possess the principles of learning based on the brain? The following sub-questions were branched from the main question:

1-To what extent do members of the teaching staff at Al-Hussein Bin Talal University possess the principles of brain-based learning?

2-Does the degree of teaching staff at Hussein Bin Talal University possess the principles of brainbased learning according to the gender variable?

3- Does the degree of teaching staff at Al-Hussein Bin Talal University possess the principles of brainbased learning according to the variable of years of experience?

9. Objectives of the study: This study aims to:

1- Knowing the extent to which members of the faculty at Hussein Bin Talal University possess the principles of brain-based learning.

2- Knowing whether the degree of teaching staff members in Hussein Bin Talal University possess the 
principles of brain-based learning, according to the gender variable.

3- Knowing whether the degree of ownership of the faculty members at Hussein Bin Talal University in the principles of brain-based learning varies according to the variable of years of experience.

\section{The importance of the study:}

The importance of the study is evident in the novelty of its approach to knowing the extent to which members of the faculty at Al-Hussein Bin Talal University possess the principles of brain-based learning - within the limits of the researcher's knowledge - according to the survey conducted for previous educational literature, and the importance of the study is highlighted through:

1- This study may provide factual data on the principles, competencies and skills needed by faculty members at Al-Hussein Bin Talal University in the light of brain-based learning.

2-This study may contribute to the development of training plans for faculty members at Al-Hussein Bin Talal University to raise their competencies in education.

3-Directing researchers to develop training programs with the aim of training new faculty members on brain-based learning strategies.

\section{Study limits and limitations:}

Spatial boundaries: Al-Hussein Bin Talal University / Jordan.

Time limits: The study was conducted in the 2017/2018 academic year.

Human boundaries: The study is conducted on a sample of faculty members at Al-Hussein Bin Talal University.

\section{Terminology of study:}

12.1 Brain-based learning: is a theory that includes knowledge of the brain's rules for meaningful learning, and the regulation of education with those rules in the brain (Caine \& Caine 1997).

It is defined procedurally: as a method of learning based on a set of principles and applications that should be employed according to educational and training seminars containing a set of planned activities and strategies, which take into account the brain functions to move towards better learning among students.

12.2 Ownership extent: It is the degree that measures what the faculty members at Al-Hussein Bin Talal University possess the principles and applications based on brain-based learning.

12.3 Members of Al-Hussein Bin Talal University faculty: They are the faculty members who teach at $\mathrm{Al}$ Hussein Bin Talal University in the academic year (2018/2017).

13. Principles of brain-based learning: a set of principles and applications that should be employed according to educational and training seminars containing a set of planned activities and strategies focused on attending the mind in the presence of high arousal, realism, fun, suspense, acquaintance, absence of threat, multiplicity and overlapping of systems in the process Educational and brain-sensitive functions towards a better learning for students. The following are detailed to these principles:

1- The brain performs many functions continuously. Learning is promoted through an environment rich with many stimuli.

2- Education is proposed to present the current content through its formation of educational strategies, such as physical activities, individual learning times, interaction with the group, artistic activities and musical activities.

3- In learning, all parts of the body are involved, and physical growth, personal relaxation, and emotional state all affect a person's ability to learn.

4- Learning suggests that children should be fully matured at different rates and that the time age may not reflect a student's preparations for learning and health specifications should also be combined: (dealing with stress, nutrition, physical exercises) in learning processes.

5- The search for meaning is innateand natural curiosity can involve it in complex, useful and challenges.

6- Learning suggests the use of current lessons and activities that stimulate brain searches for meanings through activities such as comparison, classification, stability, deduction, error analysis, supporting evidence building, abstraction and point of view analysis.

7-The brain is designed to recognize and generate patterns.

8-Learning suggests the need to achieve meaningful learning, which makes the learner able to identify patterns and link them to previous experiences.

9-Learning includes both focused attention and lateral perception.

10-Learning suggests placing materials (posters, artwork, billboards and music) outside of the learner's immediate focus.

11-Awareness that teacher enthusiasm and modeling are important signals about the value of what is being 
learned

12-Learning always includes awareness and subconscious.

13-Learning proposes to encourage active treatment through meditation, Meta cognitive processes and personal communication to help students review their learning.

14-We have at least two types of imaginative memory that record our daily experiences and radical learning that deal with root facts and skills independently.

15-The separation of information and skills from previous experiences forces the learner to rely on the root memory.

16-Focusing on radical learning ignores the personal aspect of the learner and may interfere with the chain growth in the understanding process.

17-Brain is better understood when facts and skills are embodied in the imaginary natural memory.

18-Learning suggests using methods that generate and represent experiences and experiences from the real world and also using different senses, so that activities include offers, projects, metaphor (metaphor) and the integration of content areas that embody ideas within the distinct experience.

19-Enhances learning by facing challenges and weakens in the event of a threat factor.

20-Learning proposes to create an environment (relaxed attention) slightly in terms of threat and high in degree and level of challenge.

Each brain is a unique condition, and the structure of the brain is actually changed through the learning process.

Learning suggests the use of various teaching strategies to attract the interests of individuals and to give students the opportunity to express their audiovisual and emotional desires.

\section{Previous studies:}

It is difficult to find a variable "the extent to which the principles of brain-based learning" are positioned in a combined problem and with the same expectations but modern theories of the brain have been studied in different and different forms and forms, including studies based on the Marzano model and it is one of the models based on modern brain theories and this thorny position of the research variable in previous studies, and based on the aim of the research as it is centered on demonstrating the efficiency of brain-based learning theory in activating the elements of our educational situation (programs, education strategies, mental factors, psychological factors for example), we will focus on presenting the study previous relevant learning based on the brain, whether directly entitled brain-based learning or models based on the theories of learning-based brain These are some of the relevant studies:

\subsection{Miller Study (2011)}

Miller conducted a descriptive case study of applying brain-based learning to the classroom. This study aimed to identify how to apply brain-based learning and technology-supported in the classroom. This main objective has branched from the following sub-goals:

1-Learn about the technology supported nature of the brain-based environment.

2-Identify the teacher's roles in the brain-based classroom environment.

3-Learn about the problems teachers face when employing brain-based learning and how to overcome them.

The study sample consisted of six teachers who are interested in applying brain-based learning and employ technology in their teaching and they were chosen based on recommendations from the school principal in the following specializations: (health education, physics, graphic design, French language, history and information systems) One of the leaders of the school-based learning was a sample of the school principal, in addition to the technical coordinator. The researcher used interview and observation tools to complete lists to monitor teaching methods.

\subsection{Among the results of the study:}

1-The nature of the brain-based, technology-supported environment is that of an active, learner-centered environment, which is a safe and emotional environment that depends on students 'interaction with students and students' interaction with teachers. This environment includes the learner's involvement in the learning process, does a large set of learning tools, and employs teaching Peer, as it is a computer-based environment.

2- The teacher's roles in the brain-based and technology-supported classroom environment are determined by being director and facilitator for students when they engage in the learning process, providing them with guidance, leading collaborative efforts in problem solving, providing feedback, with specific brain intelligence or control, specific abilities, patterns Learning is different to teach students with multiple needs, it must be satisfied and taken into consideration, the diversity of methods and activities, and being alternative methods

3-The problems faced by teachers when applying brain-based learning were determined by technical problems (internet crashes, CD disks, lack of color printing machines), and student problems (surfing the 
Internet, synchronization in asking questions).

14.3 (Heong Study 2011)

This study aimed to identify the level of higher-order thinking skills in the Marzano system for technical education students at the College of Technical Education at (Tun Hussein Onn) University Malaysia. The sample of this study consisted of (158) students as a random sample and used a tool the questionnaire to obtain the data of this study. The results of this study showed the following:

1-The presence (low level) of the following processes: investigation, empirical research, comparison, conclusion, support building, perseverance, invention.

2-There is a positive relationship between the levels of higher thinking skills based on Marzano's model due to gender, economic and social status.

3-The absence of statistically significant differences between the level of higher thinking skills based on the Marzano model due to gender and socioeconomic status.

4-There is a big difference in the economic and social situation at the decision-making level.

14.4 Abu Jarad (2012)

conducted a study aimed at knowing to what degree teachers use the Marzano educational model and is there a relationship with the experience and qualification of the teachers and teachers of the International Relief Agency and this study was applied in the south of Amman and the study sample included (335) Male and female teachers from the International Relief Agency (UNRWA), whose counted (1332)male and female teachers they were selected in the second semester and they were selected as a sample available from all fields and schools. The results of this study showed the following:

1-There are significant differences for using the Marzano model for learning dimensions due to experience.

2-There are significant differences for using the Marzano model for learning dimensions due to the educational qualification.

The study recommended the necessity of studying the relationship between the Marzano model and other variables since there are not many Arab studies in this field as well as studying the Marzano model and its effect on other variables such as its relationship to academic success and achievement.

14.5 Al-Towaisi Study (2017)

This study aimed to know "the extent to which the English language teachers in the Petra Education Directorate possess the necessary competencies and skills in light of the Marzano model for teacher evaluation. The sample of this study consisted of (98) teachers, and the questionnaire tool was used to obtain data for this study the results of this study showed the following:

1-The presence (a high level) of (76.49\%) of the following operations: competencies, skills and behavioral strategies of English language teachers in the Petra District, according to the Marzano model evaluation.

2-The presence of (low level) reached (52\%) in the field of preparation and planning for English language teachers in the Petra District, according to the Marzano model evaluation.

3-The absence of statistically significant differences attributable to the variable of gender and educational qualifications in the extent to which teachers possess competencies and skills in light of the Marzano model evaluation.

4-There are statistically significant differences attributable to the gender variable and the type of school variable in the extent to which teachers possess competencies and skills in light of the Marzano model evaluation.

\section{Methods and procedures}

The study sample consisted of faculty members at Hussein Bin Talal University for the academic year (2017/2018), as the number of faculty members reached (350).

15.1 Study sample:

The sample was chosen by intentional method and the number of faculty members reached (70) and the following table shows the distribution of the sample members: 
Table 1. Distribution of the study sample according to the gender and experience variable

\begin{tabular}{|c|c|c|c|}
\hline total & PERCENTIGE \% & number & Variable \\
\hline 54 & $\begin{array}{l}77.1 \\
22.8 \\
\end{array}$ & $\begin{array}{l}54 \\
16 \\
\end{array}$ & $\begin{array}{l}\text { Male } \\
\text { Female } \quad \text { Gender }\end{array}$ \\
\hline 70 & $\mathbf{1 0 0 . 0}$ & 70 & $\begin{array}{c}\text { Total } \\
\end{array}$ \\
\hline $\begin{array}{l}15 \\
15 \\
40\end{array}$ & $\begin{array}{l}21.4 \\
21.4 \\
57.2\end{array}$ & $\begin{array}{l}15 \\
15 \\
40\end{array}$ & $\begin{array}{c}\text { Less than } 4 \text { years } \text { Experience } \\
\text { From } 5 \text { to } 10 \\
\text { More than } 10 \text { years }\end{array}$ \\
\hline 70 & 100.0 & 70 & Total \\
\hline
\end{tabular}

15.2 Study tool:

To achieve the objectives of the study, the researcher prepared and developed a questionnaire for the study by reviewing theoretical literature and previous studies such as (Jensen, 2000), (Caine \& Caine 1990), (Caine R, 1997) and (Heong, 2011) study, (Miller; 2011) study. The researcher will formulate the paragraphs of the study tool, which totaled (38).paragraphs accordingly to the Liker five-point scale to determine the degree of response:(very high was given (5) degrees, high (4) degrees were given, and medium (3) degrees were given, low two (2) degrees were given, and very low (1) one degree was given.

The category length was calculated as follows: $3 / 1-4=1.33$

Based on this result, the levels are as follows:

From 1 to 2.33 low.-

From 2.34 to 3.67 intermediate levels.-

From 3.68 to 5 high.-

15.3 Validate the study tool:

The validity of the study tool was verified by presenting, in its initial form, to a number of faculty arbitrators who specialize in curricula and teaching methods at Hussein Bin Talal University.

15.4 The stability of the study tool:

The stability of the study tool was verified in two ways:

The first method: Test-retest method, by applying the questionnaire to a sample from outside the study of faculty members and its number (20) members, then re-applying them two weeks after the first time, then using the Pearson correlation coefficient to find a factor Stability, has reached the resolution $(0.83)$.

The second method: Using the Cronbach's Alphaequation to calculate the internal consistency coefficient, and it was (0.763) for the paragraphs as a whole.

15.5 Study variables:

The study included the following variables:

First: the independent variables included

Gender: It has two levels (male, female). (1-

2-(Experience: it has three levels (4 years less, 12-5 years, 12 years or more).

Second: The dependent variable: (the extent to which members of the teaching staff at Al-Hussein Bin Talal University) possess the principles of brain-based learning.

15.6 Statistical processing:

To answer the main question of the study, arithmetic averages, standard deviations and grade was used, T-test, One Way ANOVA was used.

\section{Results of the study:}

16.1The results of the main question, which states: How well do faculty members at Al-Hussein Bin Talal University possess the principles of brain-based learning?

To answer this question, arithmetic averages, standard deviations and ranks were calculated to the degree that faculty members at Al-Hussein Bin Talal University possess the principles of brain-based learning. Table No. 2 shows that: 
Table 2 .Arithmetic averages, standard deviations and ranks for the degree to which the faculty members at Al-

Hussein Bin Talal University possess the principles of brain-based learning.

\begin{tabular}{|c|c|c|c|c|c|}
\hline No & Paragraph & Average & $\begin{array}{l}\text { Deviation } \\
\text { Standard }\end{array}$ & $\begin{array}{l}\text { Relative } \\
\text { Importance\% }\end{array}$ & Rank \\
\hline & First Domain / Principles of Brain Based Learning & & & & \\
\hline $1-$ & I realize that each brain is a unique condition. & 4.62 & 0.624 & 90.20 & 1 \\
\hline $2-$ & $\begin{array}{l}\text { I have the knowledge that radical learning deals with } \\
\text { root facts and skills independently. }\end{array}$ & 3.71 & 0.865 & 72.20 & 5 \\
\hline 3- & $\begin{array}{l}\text { I have knowledge that understanding the brain is better } \\
\text { when facts and skills are embodied in the imaginary } \\
\text { (imaginary) natural memory. }\end{array}$ & 3.60 & 0.813 & 72.00 & 9 \\
\hline 4- & $\begin{array}{l}\text { I have the knowledge that learning is enhanced by } \\
\text { facing challenges. }\end{array}$ & 3.55 & 0.787 & 67.00 & 23 \\
\hline 5- & $\begin{array}{l}\text { I have knowledge that learning is impaired if there is a } \\
\text { threat factor. }\end{array}$ & 3.41 & 0.777 & 68.20 & 20 \\
\hline 6- & $\begin{array}{l}\text { I have knowledge that learning involves all parts of } \\
\text { the body }\end{array}$ & 3.50 & 0.658 & 67.60 & 22 \\
\hline 7- & $\begin{array}{l}\text { I have experience that the structure of the brain is } \\
\text { actually changing through the learning process. }\end{array}$ & 3.53 & 0.786 & 70.00 & 15 \\
\hline 8- & $\begin{array}{l}\text { I have knowledge that physical growth, personal } \\
\text { relaxation and emotional state affect a person's ability } \\
\text { to learn. }\end{array}$ & 3.50 & 0.723 & 70.00 & 15 \\
\hline 9- & $\begin{array}{l}\text { I have knowledge that the process of searching for } \\
\text { meaning is innate. }\end{array}$ & 4.03 & 0.598 & 80.60 & 4 \\
\hline 10- & $\begin{array}{l}\text { I have knowledge that the brain is designed to } \\
\text { recognize and generate patterns. }\end{array}$ & 3.53 & 0.954 & 70.60 & 13 \\
\hline 11- & $\begin{array}{l}\text { I understand that achieving realization requires not } \\
\text { separating emotions from learning. }\end{array}$ & 3.03 & 0.854 & 66.70 & 25 \\
\hline $12-$ & $\begin{array}{l}\text { I understand that achieving remembering requires not } \\
\text { separating emotions from learning. }\end{array}$ & 3.53 & 0.872 & 70.60 & 13 \\
\hline 13- & $\begin{array}{l}\text { I have experience that every brain can perceive and } \\
\text { generate molecules and colleges at the same time. }\end{array}$ & 4.28 & 0.770 & 85.60 & 2 \\
\hline 14- & $\begin{array}{l}\text { I have experience that learning includes both focused } \\
\text { attention and lateral perception. }\end{array}$ & 3.49 & 0.801 & 69.80 & 16 \\
\hline $15-$ & $\begin{array}{l}\text { I have the knowledge that learning involves awareness } \\
\text { and subconscious. }\end{array}$ & 3.48 & 0.764 & 68.82 & 17 \\
\hline $16-$ & $\begin{array}{l}\text { I have knowledge that we have at least two types of } \\
\text { imaginative memory that record our daily experiences } \\
\text { and experiences. }\end{array}$ & 3.38 & 0.648 & 67.80 & 22 \\
\hline & The second Domain / brain-based learning strategies & & & & \\
\hline $17-$ & I have brain-based learning strategies and methods. & 3.40 & 0.650 & 68.00 & 21 \\
\hline 18- & $\begin{array}{l}\text { I have strategies that guide how to implement } \\
\text { assignments. }\end{array}$ & 3.50 & 0.782 & 70.00 & 15 \\
\hline 19- & $\begin{array}{l}\text { I have the ability to design an educational situation in } \\
\text { the light of brain-based learning. }\end{array}$ & 3.32 & 0.762 & 66.40 & 24 \\
\hline $20-$ & $\begin{array}{l}\text { The promotion of learning takes place in an } \\
\text { environment rich with many stimuli. }\end{array}$ & 3.44 & 0.761 & 66.80 & 18 \\
\hline 21- & $\begin{array}{l}\text { I have knowledge that the brain performs many } \\
\text { functions continuously. }\end{array}$ & 4.06 & 0.879 & 81.20 & 3 \\
\hline $22-$ & $\begin{array}{l}\text { Musical activities all contribute to increasing students' } \\
\text { experiences. }\end{array}$ & 3.43 & 0.739 & 66.80 & 19 \\
\hline 23- & $\begin{array}{l}\text { Strategies used include group interaction, artistic } \\
\text { activities, and individual learning }\end{array}$ & 3.69 & 0.675 & 73.80 & 6 \\
\hline 24- & $\begin{array}{l}\text { Health specifications (stress management, nutrition, } \\
\text { and physical exercises) must be incorporated into the } \\
\text { learning process. }\end{array}$ & 3.57 & 0.798 & 71.40 & 10 \\
\hline $25-$ & $\begin{array}{l}\text { Take advantage of current lessons and activities that } \\
\text { spark brain searches for meanings. }\end{array}$ & 3.69 & 0.902 & 73.80 & 6 \\
\hline
\end{tabular}




\begin{tabular}{|c|c|c|c|c|c|}
\hline No & Paragraph & Average & $\begin{array}{l}\text { Deviation } \\
\text { Standard }\end{array}$ & $\begin{array}{l}\text { Relative } \\
\text { Importance \% }\end{array}$ & Rank \\
\hline $26-$ & $\begin{array}{l}\text { I understand that the current information in the content } \\
\text { (real life science, purposeful education) makes the } \\
\text { learner able to identify patterns and relate them to } \\
\text { previous experiences. }\end{array}$ & 3.65 & 0.842 & 73.00 & 8 \\
\hline $27-$ & $\begin{array}{l}\text { I am working to build a classroom environment that } \\
\text { promotes positive behaviors between students and } \\
\text { teachers and about their work. }\end{array}$ & 3.54 & 0.921 & 70.80 & 12 \\
\hline $28-$ & $\begin{array}{l}\text { Encourage students to learn about their feelings and } \\
\text { how the emotional climate affects their learning. }\end{array}$ & 3.47 & 0.819 & 69.41 & 18 \\
\hline 29- & $\begin{array}{l}\text { Avoid separating information from its framework so } \\
\text { that learning is not more difficult. }\end{array}$ & 3.49 & 0.743 & 64.80 & 16 \\
\hline $30-$ & $\begin{array}{l}\text { Design activities that require full mental interaction } \\
\text { and a high degree of communication. }\end{array}$ & 3.41 & 0.868 & 68.20 & 20 \\
\hline $31-$ & $\begin{array}{l}\text { Instruct students to place materials (such as posters) } \\
\text { outside of the learner's immediate focus. }\end{array}$ & 3.44 & 0.741 & 68.80 & 18 \\
\hline $32-$ & $\begin{array}{l}\text { To find value on what is going on, be sure to be } \\
\text { enthusiastic and modeling. }\end{array}$ & 3.54 & 0.721 & 72.80 & 12 \\
\hline $33-$ & $\begin{array}{l}\text { Encourage active treatment through meditation and } \\
\text { meta cognition processes. }\end{array}$ & 3.51 & 0.837 & 72.20 & 14 \\
\hline $34-$ & $\begin{array}{l}\text { I try not to focus on radical learning because it ignores } \\
\text { the personal aspect of the learner. }\end{array}$ & 3.55 & 0.854 & 73.30 & 11 \\
\hline $35-$ & $\begin{array}{l}\text { Use techniques that generate and represent } \\
\text { experiences and experiences from the real world. }\end{array}$ & 3.43 & 0.738 & 68.77 & 19 \\
\hline $36-$ & $\begin{array}{l}\text { Creating a relaxed environment of low attention in } \\
\text { terms of threat, and high in degree and level of } \\
\text { challenge. }\end{array}$ & 3.68 & 0.848 & 75.00 & 7 \\
\hline $37-$ & $\begin{array}{l}\text { Use a variety of education strategies to attract student } \\
\text { interest, and give them the opportunity to express their } \\
\text { audio, visual or emotional desires. }\end{array}$ & 3.43 & 0.654 & 69.00 & 19 \\
\hline $38-$ & $\begin{array}{l}\text { Use the different senses to include activities, Offers, } \\
\text { Projects, metaphors, and integration of content areas } \\
\text { that embody ideas within the distinct experience. }\end{array}$ & 3.53 & 0.786 & 72.00 & 13 \\
\hline
\end{tabular}

It is clear from Table No. (2) that the paragraphs after the field of principles of brain-based learning have ranged between the relative importance of $(90.20 \%)$, which is for the paragraph that states (I realize that each brain is a unique case) and came in the first order and this indicates that the members of the study sample They possess this principle with a very high degree while the paragraph (I have knowledge that the brain is designed to perceive and generate patterns) came in the last order within this dimension and the relative importance of it $(66.70 \%)$ and this value expresses the possession of the study sample individuals to this principle with an average degree.

With regard to the second field, which is the field related to brain-based learning strategies, the results indicate in Table No. (2) the paragraph that states (I have knowledge that the brain performs many functions continuously) came in the first order, the relative importance of this paragraph reached $(81.20 \%)$ and this It means that the members of the study sample possess this strategy in a very high degree, and the paragraph that reads (I have the ability to design the educational situation in light of learning based on the brain) came in the last order, the relative importance of this paragraph reached (66.40\%) and this value reflects the ownership of the study sample members For this strategic A medium degree.

16.2 The results of the second question: Does the degree of teaching staff at Al-Hussein Bin Talal University possess the principles of brain-based learning according to the gender variable?

To answer the second question, arithmetic averages and standard deviations were calculated and a test $(\mathrm{T})$ was performed to examine the differences between group averages according to the gender variable and Table No. (3) Illustrates this: 
Table 3. Mathematical Averages, Standard Deviations, and (T) Test Value for the Gender Variable.

\begin{tabular}{|l|l|l|l|l|l|}
\hline Gender & arithmetic, standard & deviation & (T value) & significance value & level of value \\
\cline { 1 - 4 } male & 185.47 & 11.963 & 0.539 & 0.592 & not significant \\
\cline { 1 - 5 } Female & 181.70 & 26.220 & & & \\
\hline
\end{tabular}

It is clear from Table No. (3) that the value of the statistic (T) has reached (0.539) which is not statistically significant at the level of significance $(\alpha=0.05)$ and this indicates that the differences between the mean of the responses of the individuals of the study sample on the paragraphs of the study tool are not significant or they are not essential differences between male and female faculty members in the extent of their possession of brainbased learning principles and strategies and this result can be explained by the fact that all faculty members have a keenness to obtain knowledge to the same degree.

16.3 The results of the third question: Does the degree of teaching staff at Hussein Bin Talal University possess the principles of brain-based learning according to the variable of years of experience?

To answer the third question, arithmetic averages and standard deviations were calculated and (The One Way Anova) test was performed to check the differences between the group averages according to the variable of years of experience and Tables No. (4) and No. (5) Illustrate this:

Table 4. Arithmetic averages and standard deviations according to variable years of experience

\begin{tabular}{|r|c|c|c|}
\hline Experiences years & Less than 4 years & From 5-10 years & More than 10 years \\
\hline Less than 4 years & 0.366 & 0.365 & $* 0.013$ \\
\hline From 5-10 years & - & - & - \\
\hline More than 10 years & - & - & - \\
\hline
\end{tabular}

It is clear from Table No. (4) That the highest arithmetic average was in favor of the years of experience category (more than 10 years). The average of this category was (195.50) followed by the years of experience category (less than 4 years), which is (189.67). Experience (5-10 years): (188.27). It is clear from the arithmetic mean of the levels of variable years of experience that there are differences between these averages and to ensure the extent of the significance of these differences, a (One Way Anova) analysis test was performed to examine the differences between the averages and Table No. (5) Illustrates this:

Table 5. The results of the mono-variance analysis test for years of experience variable

\begin{tabular}{|r|r|r|r|r|r|}
\hline $\begin{array}{l}\text { Source of } \\
\text { variance }\end{array}$ & Sum of squares & Freedom degrees & Average squares & Value (F) & $\begin{array}{l}\text { Significant } \\
\text { level }\end{array}$ \\
\hline Between groups & 4351.311 & 3 & 1450.437 & 2.765 & 0.049 \\
\hline Inside groups & 33567.331 & 66 & 524.494 & - & - \\
\hline Total degree & 37918.841 & 69 & - & - & - \\
\hline
\end{tabular}

It is clear from Table No. (5) that the value of the test $(\mathrm{F})$ has reached (2.765), which is a statistically significant value at the level of significance $(\alpha=0.05)$, which means that the differences between the averages of levels of variable years of experience have significant significance and to verify the substance and direction of this Differences between levels of years of experience variable (LSD) was done for dimensional comparisons and Table No. (6) Illustrates this:

Table 6. LSD test results for dimensional comparisons of years of experience variable

\begin{tabular}{|r|c|c|c|}
\hline Experiences years & Less than 4 years & From 5-10 years & More than 10 years \\
\hline Less than 4 years & 0.366 & 0.365 & $* 0.013$ \\
\hline From 5-10 years & - & - & - \\
\hline More than 10 years & - & - & - \\
\hline
\end{tabular}

Table (6) shows that the value of dimensional comparisons between levels of variable years of experience was statistically significant between the level of years of experience (less than four years) and the level of years of experience (more than 10 years) and with a value of $(0.013 *)$ which is a function at the level of significance $(\alpha=0.05)$ Looking at Table No. (4), it appears that the differences between the two levels are due to the benefit of the study sample individuals who have experience (more than 10 years), where the arithmetic mean for this level of the variable years of experience levels (195.5), which is higher than the arithmetic mean for the individuals of a sample The study is from the level of years of experience (less than 4 years), where it reached (189.67), which means that the differences are between the recipient It is attributed to the benefit of the members of the study sample who have years of experience (more than 10 years).

\section{Conclusion:}

1. The researcher recommends applying similar studies in other universities.

2. It recommends researchers to take advantage of the study tool that the researcher has performed and applied it to similar studies.

3. The researcher recommends conducting training courses on the use of brain-based learning strategies. 
4. Training students and teachers of colleges of education on brain-based learning strategies.

\section{References}

Abd Alkarim, M. (2010).Instructional design, according to the theories of brain-based learning and its impact on the collection of the second medium students in chemistry.scientific journal open, 8 (44), 62-71.

Abu Jarad, Muhammad Abd al-Salam (2012) Degree of teachers' use of the dimensions of the Marzano educational model, unpublished master's thesis, The Hashemite University, Zarqa, Jordan.

Alfilmbani, D. (2014). The impact of a training program based on brain-based learning and motivation level of proficiency in the development of skills beyond learning and academic achievement among students of the Faculty of Education, Kingdom of Saudi Arabia. (Unpublished Doctoral dissertation). Cairo University, Egypt.

Al-Naqa, Mahmoud Kamel (1997) "The competency-based educational program, its foundations and procedures", Cairo, Arab Republic of Egypt.

Al-Qarni, Khafir Al-Qarni (2015) The effect of using brain-based learning strategy in science education on developing high-ranking thinking and some habits of mind among middle-grade second-grade students with different brain control patterns, unpublished doctoral thesis, College of Education, Umm Al-Qura University.

Al-Salti, Nadia Samih (2009), Brain-Based Learning, Dar Al-Masirah for Publishing, Distribution and Printing, Amman.

Al-Toisi, Aisha (2017) "The extent to which the English language teachers in Petra Education Directorate possess the necessary competencies and skills in the light of the Marzano Model of Teacher Calendar, Unpublished Master Thesis, Hussein Bin Talal University, Maan, Jordan.

Burnett, S. (2010). Substanting constructivism from a brain-based perspective; international journal of interdisciplinary social sciences. 5 (4). 145.

Caine, R. \& Caine, G. (1990). Understanding a brain based approach to learning and teaching. Educational leadership, 48(2), 66-70.

Caine, R.N., \& Caine, G. (1997).Education on the edge of possibility. Alexandria, VA: Association for Supervision andCurriculum Development.

Heong,yee mei; Othman,widad Binti;yunaos, Jalilani, bin md; Kiong,Tee Tze; Hassan,razali Bin and Mohamad, mohaffy Za Binti (2011) The Level Of Marzano Higher Order Thinking Skills among Technical Education Students,Internotional Journal Of Social Science and Humanity, Vol .1 ,No.2.

Jensen,E.(2000) , 10 most effective tips for using brain based teaching and learning.http://WWW.jensen learning.com/pdf/10 most Effective Tips.pdf.

Katame, Naifeh (2001) "Teaching Psychology", Dar Al-Sharq for Publishing and Distribution, Amman, Jordan.

Kim, K. (2009). Can we trust creativity tests? A review of the Torrance test of creative thinking (ttct).Creativity research journal. 18(1), 3-14.

Miller, A. L. (2004): A descriptive case study of the implementation of brain based learning with technological support in a rural high school http://www.learningandthebrain.com/0001/miller05.htm. 